\title{
Penerapan Literasi Sains Basis Kelas oleh Guru PAUD di Kota Surakarta
}

\author{
Vera Sholeha ${ }^{\circledR}$, Siti Wahyuningsih"1, Ruli Hafidah', Muhammad Munif Syamsuddin', \\ Adriani Rahma Pudyaningtyas', Nurul Kusuma Dewi', Novita Eka Nurjanah ${ }^{1}$ \\ Pendidikan Guru Pendidikan Anak Usia Dini, Universitas Sebelas Maret, Indonesia(1) \\ DOI: $10.31004 /$ obsesi.v6i3.1237
}

\begin{abstract}
Abstrak
Hasil PISA 2018 menunjukkan rata-rata skor sains negara-negara OECD adalah 489, namun Indonesia baru mencapai skor 396 (OECD, 2019) yang artinya masih berada di level bawah. Padahal sejak 2017 Indonesia sudah menggalakkan Gerakan Literasi Nasional. Penelitian ini merupakan penelitian survey yang bertujuan untuk mengetahui sejauh mana penerapan literasi sains pada PAUD di Kota Surakarta. Populasi dari penelitian ini adalah seluruh guru PAUD di Surakarta dan sampel dari penelitian ini adalah 64 responden. Data dikumpulkan menggunakan kuesioner respon guru. Teknik analisis data yang digunakan adalah teknik persentase. Hasil persentase dari penelitian ini menunjukkan bahwa indikator literasi sains basis kelas mendapatkan hasil yang bervariasi. Adapun hambatan yang dialami oleh guru dalam penerapan literasi sains diantaranya adalah guru belum pernah mengikuti pelatihan tentang pengembangan pembelajaran literasi sains di PAUD, guru belum memahami bagaimana penerapan literasi sains, serta sarana dan prasarana sekolah yang belum memadai.
\end{abstract}

Kata Kunci: anak usia dini; literasi sains; pembelajaran sains.

\begin{abstract}
The 2018 PISA results show the average science score of OECD countries is 489, but Indonesia has only reached a score of 396 (OECD , 2019) which means it is still at the lower level. In fact, since 2017 Indonesia has been promoting the National Literacy Movement. This is a survey study that aims to determine the extent of the application of scientific literacy in Early Childhood Education in Surakarta City. The population of this study were all early childhood education teachers in Surakarta and the sample of this study was 64 respondents. Data were collected using a teacher response questionnaire. The data analysis technique used is the percentage technique. The results of the percentage of this study indicate that the indicators of class-based science literacy get varying results. The obstacles experienced by teachers in the application of scientific literacy are; the teacher has never attended training on the development of science literacy learning in early childhood education, the teacher does not understand how to apply scientific literacy, and inadequate school facilities and infrastructure.
\end{abstract}

Keywords: early childhood; science literacy; science learning.

Copyright (c) 2021 Vera Sholeha, et al.

$\square$ Corresponding author:

Email Address : verasholeha@staff.uns.ac.id (Jalan Slamet Riyadi No. 449, Pajang, Surakarta)

Received 30 March 2021, Accepted 30 October 2021, Published 25 November 2021 


\section{PENDAHULUAN}

Sains merupakan salah satu bidang penting dalam pendidikan anak usia dini (Barenthien et al., 2020). Anak-anak secara alamiah memiliki rasa kagum dan terdorong untuk bereksplorasi untuk memahami dunia dan lingkungan tempat tinggal mereka. Anak-anak juga memiliki potensi untuk belajar dengan berinteraksi dengan lingkungan mereka (National Research Council, 2010). Şentürk \& Sari (2018) juga menjelaskan bahwa anak usia dini memiliki rasa ingin tahu yang mendalam. Mereka ingin mengetahui dan menyelidiki lingkungan sehingga mereka berusaha melakukan berbagai hal. Untuk itu, masa usia dini merupakan waktu yang tepat bagi guru untuk melibatkan anak dalam sains (Gerde et al., 2018).

Anak-anak mendapatkan pengetahuan sains seperti makhluk hidup membutuhkan makanan untuk bertahan hidup dan beberapa keterampilan seperti pengeringan, penyembuhan, dan lain-lain melalui bantuan orang dewasa yang lebih berpengetahuan (Mayer, 2004). Jackman (2012) menjelaskan bahwa sains bagi anak usia dini merupakan suatu gabungan dari proses keterampilan (bagaimana anak belajar) serta konten (apa yang dipelajari oleh anak). Proses keterampilan ini melibatkan peserta didik (anak) untuk memproses informasi baru melalui pengalaman yang konkrit atau nyata. Morrison (2012) menambahkan bahwa pembelajaran sains dapat menstimulasi kemampuan pemecahan masalah pada anak usia dini. Keterampilan seperti mengamati, mengeksplorasi dan menemukan adalah penting dan mendasar untuk pengajaran dan pembelajaran sains dalam pendidikan anak usia dini. Pendidikan sains yang efektif di masa pra-sekolah menumbuhkan rasa ingin tahu dan kesenangan anak-anak dengan mengeksplorasi lingkungan dan menjadi pendidikan dasar sains di pendidikan dasar dan menengah (NSTA Position Statement: Early Childhood Science Education Introduction, 2012).

Pendidik anak usia dini dapat membangun pertanyaan, semangat, dan antusiasme untuk membantu anak belajar sains. Pendidik dapat menumbuhkan pengetahuan ilmiah dengan mempersiapkan lingkungan yang kaya, baik di dalam atau di luar sekolah atau rumah, dengan memperkenalkan kosakata ilmiah selama kegiatan, belajar selama jangka yang panjang, dan dengan memberikan banyaknya kesempatan kepada anak-anak untuk memecahkan dan menyelidiki masalah (Bosse \& Anderson, 1946). Jika guru dapat menerapkan pembelajaran sains dengan tepat, maka dapat mewujudkan anak yang berliterasi sains. Bybee (2008) mengungkapkan bahwa literasi sains harus dimulai sedini mungkin. Hal ini didukung dengan pendapat Husna Handayani et al (2019) yang menjelaskan bahwa anak usia dini memiliki potensi pada kemampuan literasi sains, sehingga dapat mulai dipupuk dan kembangkan sejak dini.

Literasi sains ditujukan untuk mengetahui kemampuan siswa dalam menanggapi isuisu sains dengan menggunakan gagasan-gagasan ilmiah (Aditomo \& Faridz, 2019). Cakupan dari literasi sains ini tidak hanya pada kemampuan anak dalam mengendalikan proses kognitif dan kemampuan pemecahan masalahnya secara pribadi, namun lebih dari itu, yaitu mengenai kemampuan anak dalam memecahkan masalah sosial secara ilmiah (Widayati et al, 2020) mengungkapkan bahwa cakupan dari keterampilan literasi sains ini. Hal ini diperkuat dengan pendapat Avikasari et al (2018) yang menjelaskan bahwa melalui literasi sains diharapkan anak dapat menanya, menemukan, atau memberikan jawaban atas pertanyaanpertanyaan yang muncul dari rasa keingintahuannya akan segala hal. Rasa ingin tahu tersebut harus diarahkan pada sikap ilmiah dan pemikiran ilmiah sehingga anak dapat memecahkan masalah yang dihadapinya secara ilmiah. Lebih lanjut, Zahro et al (2019) menjelaskan bahwa sains pada anak usia dini mempelajari pengetahuan tentang fakta atau gejala yang ada di lingkungan sekitar anak, selanjutnya, bagaimana pengetahuan tersebut dapat bermanfaat bagi kehidupan mereka. Dengan begitu, pengembangan literasi sains akan membuat anak kian peka terhadap lingkungan sekitarnya (ZR \& Eliza, 2020). 
Pendidikan anak usia dini diharapkan mampu menjadi wadah untuk mengembangkan literasi anak usia dini melalui aktivitas atau pembelajaran sains secara terintegrasi dalam tema-tema sesuai dengan kurikulum PAUD yang berlaku. Menanamkan serta memupuk literasi sains pada anak usia dini hendaknya dilakukan secara ramah dalam arti sesuai dengan karakteristik dan tahap perkembangan anak usia dini (Samsiah, 2018).

Hasil PISA 2018 menunjukkan rata-rata skor sains negara-negara OECD adalah 489, namun Indonesia baru mencapai skor 396 (OECD, 2019). Nilai ini menunjukkan penurunan dibandingkan dengan nilai tahun 2015 yaitu 403. Hal ini menunjukkan adanya gap dalam membelajarkan pembelajaran sains. Dalam sistem pendidikan nasional, konsep dan pola pikir pembelajaran sains menggunakan pendekatan saintifik, dan discovery inquiry. Namun faktanya hal ini belum diimplementasikan dalam pembelajaran di kelas. Padahal sejak 2017 Indonesia sudah menggalakkan Gerakan Literasi Nasional. Dalam hal ini, guru memiliki tugas dan peran yang penting dalam meningkatkan literasi sains di sekolah dan masyarakat.

Pereira et al (2020) menjelaskan bahwa guru taman kanak-kanak harus memiliki bekal ilmu pengetahuan yang kuat dan mendalam tentang konsep-konsep yang berkaitan dengan setiap kegiatan sains yang akan memungkinkan pendekatan yang benar dan tepat terhadap konsep-konsep ilmiah, karena hal ini akan menentukan sifat (dan keakuratan) pengetahuan yang akan dipelajari oleh anak. Guru membutuhkan pengetahuan sains sehari-hari untuk memahami kemungkinan situasi pembelajaran dalam sains, menjelaskannya pada tingkat sehari-hari, dan memberikan dukungan yang sesuai dalam situasi ini (Barenthien et al., 2020). Selain itu, guru perlu mengemas pembelajaran sains dalam bentuk permainan (Omaga \& Alieto, 2019). Pendekatan berbasis bermain untuk sains memungkinkan anak-anak untuk memahami konsep sains yang ia pelajari (Sliogeris \& Almeida, 2019).

\section{METODOLOGI}

Penelitian ini menggunakan metode deskriptif-survei. Responden dalam penelitian ini sejumlah 64 guru PAUD. Teknik pengambilan sampel pada penelitian ini menggunakan random sampling dengan memberikan kuesioner kepada guru PAUD dari level latar belakang pendidikan yang berbeda-beda di Surakarta, Indonesia. Instrumen kuesioner digunakan untuk mengidentifikasi penerapan literasi sains basis kelas pada pembelajaran di PAUD. Indikator penelitian yang digunakan mengacu pada indikator literasi sains basis kelas yang tertuang pada Buku Materi Pendukung Literasi Sains yang dikembangkan oleh Kementerian Pendidikan dan Kebudayaan (2017). Secara sederhana, desain penelitian ini dapat digambarkan seperti bagan 1 .

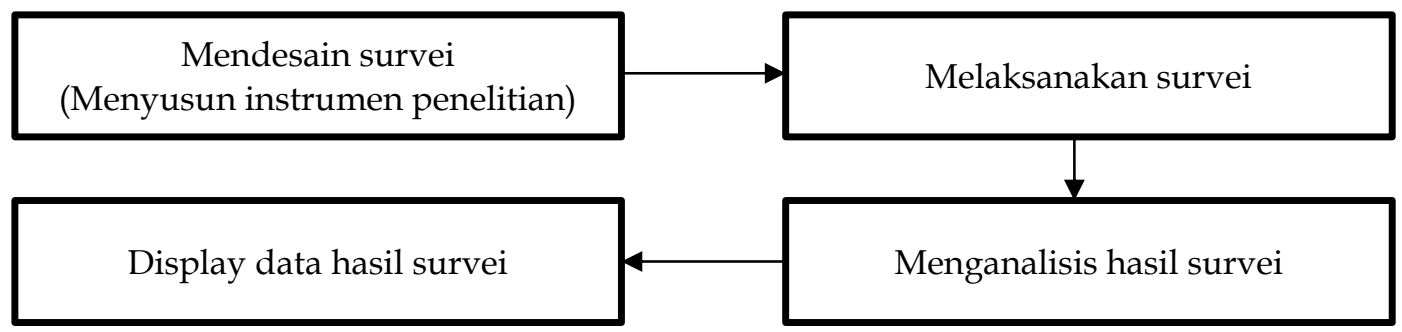

Bagan 1. Desain Penelitian Survei

Teknik analisis data yang digunakan dalam penelitian ini adalah perhitungan presentase dengan menggunakan rumus 1.

$$
P=\frac{F}{n} \times 100 \%
$$

Rumus 1. Perhitungan persentase 
Setelah dipresentasekan, nilai dari presentase tersebut dikategorikan pada kriteria kalkulasi presentase pada tabel 1. Selanjutnya, data demografi responden dalam penelitian ini dideskripsikan pada tabel 2.

Tabel 1. Kriteria Penilaian Skor

\begin{tabular}{cc}
\hline Presentase & Informasi \\
\hline 0 & Tidak ada \\
$1-24$ & Hampir tidak ada \\
$25-49$ & Kurang dari sebagian \\
50 & Sebagian dari \\
$51-74$ & Lebih dari sebagian \\
$75-99$ & Sebagian besar \\
100 & Seluruhnya \\
\hline
\end{tabular}

Tabel 2. Data Responden

\begin{tabular}{llc}
\hline & Responden & Presentase \\
\hline Jenis & Laki-laki & 1.6 \\
kelamin & Perempuan & 98.4 \\
Pendidikan & Sarjana & 76.6 \\
& Program PPG & 21.9 \\
& Magister & 1.5 \\
\hline
\end{tabular}

\section{HASIL DAN PEMBAHASAN}

Literasi sains adalah tujuan utama dan fundamental dari pendidikan sains (Şentürk \& Sari, 2018). Lebih lanjut Laugksch (Garner-O'Neale et al., 2013) menjelaskan bahwa istilah 'literasi sains' diciptakan oleh Paul Hurd pada akhir 1950-an dan digunakan untuk menggambarkan pemahaman sains dan aplikasinya pada masyarakat. Hasil survei yang dilakukan menunjukkan bahwa sebagian besar responden telah mengembangkan literasi sains di sekolahnya, penjabaran dari penerapan literasi sains basis kelas dapat dilihat pada Tabel 3.

Tabel 3. Hasil Analisis Data Kuesioner

\begin{tabular}{|c|c|c|c|c|}
\hline \multirow[b]{2}{*}{ No } & \multirow[b]{2}{*}{ Item } & \multicolumn{3}{|c|}{ Presentase } \\
\hline & & $\begin{array}{l}\text { Tidak } \\
\text { pernah }\end{array}$ & $\begin{array}{l}\text { Kadang- } \\
\text { kadang }\end{array}$ & Sering \\
\hline 1 & $\begin{array}{l}\text { Mengikuti pelatihan guru terkait dengan pembelajaran } \\
\text { sains untuk anak usia dini (dalam } 1 \text { tahun) }\end{array}$ & 39.1 & 56.3 & 4.6 \\
\hline 2 & $\begin{array}{l}\text { Mengikuti pelatihan guru terkait dengan pembelajaran } \\
\text { non sains untuk anak usia dini (dalam } 1 \text { tahun) }\end{array}$ & 10.9 & 71.9 & 17.2 \\
\hline 3 & $\begin{array}{l}\text { Menerapkan literasi sains dalam pembelajaran (dalam } 1 \\
\text { semester) }\end{array}$ & 1.5 & 56.3 & 42.2 \\
\hline 4 & Menerapkan pembelajaran sains berbasis permasalahan & 6.2 & 64.1 & 29.7 \\
\hline 5 & Menerapkan pembelajaran sains berbasis proyek & 15.6 & 54.7 & 29.7 \\
\hline 6 & $\begin{array}{l}\text { Menerapkan pembelajaran nonsains yang melibatkan } \\
\text { unsur literasi sains }\end{array}$ & 6.2 & 62.5 & 31.3 \\
\hline 7 & $\begin{array}{l}\text { Terdapat produk yang dihasilkan oleh anak melalui } \\
\text { pembelajaran sains berbasis proyek dalam satu semester }\end{array}$ & 14.1 & 65.6 & 20.3 \\
\hline
\end{tabular}

Berdasarkan tabel 3, pada indikator jumlah pelatihan guru sains dan nonsains (item 1 dan item 2) menunjukkan lebih dari sebagian guru PAUD di Surakarta telah mengikuti pelatihan guru terkait dengan pembelajaran sains dan nonsains untuk anak usia dini dalam kurun waktu 1 tahun, bahkan untuk pelatihan nonsains sebagian besar guru telah 
mengikutinya. Berdasarkan data hasil kuesioner dengan pertanyaan terbuka, dapat disimpulkan bahwa beberapa pelatihan terkait dengan pembelajaran sains yang diikuti oleh guru-guru adalah pelatihan science for kids, pelatihan pembelajaran STEAM di PAUD, pelatihan penyusunan perangkat pembelajaran dengan pendekatan TPACK dan HOTS. Sedangkan pelatihan pembelajaran nonsains yang diikuti oleh guru diantaranya pelatihan penyusunan kurikulum dan penilaian pembelajaran, pelatihan icebreaking, pengelolaan pembelajaran berbasis IT, workshop APE, pelatihan mendongeng, dan pelatihan brain gym.

Pada indikator memanfaatkan dan menerapkan literasi sains dalam pembelajaran (item 3) menunjukkan bahwa sebagian besar guru telah menerapkan literasi sains dalam pembelajaran dalam kurun waktu 1 semester. Selanjutnya pada indikator menerapkan pembelajaran sains berbasis permasalahan dan berbasis proyek (item 4, 5), menunjukkan bahwa sebagian besar guru PAUD di Surakarta telah menerapkannya, baik pada pendekatan pembelajaran berbasis pemeacahan masalah maupun berbasis proyek. Lebih lanjut, pada indikator menerapkan pembelajaran nonsains yang melibatkan unsur literasi sains (item 6) menunjukkan bahwa sebagian besar guru telah menerapkan pembelajaran nonsains yang melibatkan unsur literasi sains.

Pada indikator terakhir yaitu menghasilkan produk yang dihasilkan peserta didik melalui pembelajaran sains berbasis proyek (item 7) menunjukkan bahwa sebagian besar guru telah memiliki produk yang dihasilkan oleh anak melalui pembelajaran sains berbasis proyek dalam satu semester. Produk-produk tersebut diantaranya miniature gunung api meletus, miniature rumah, apolo air (tekanan udara), lampu parallel seri, tanaman yang ditanam sendiri oleh anak, kapal air, baling-baling/ kincir angin dari kertas, robot sederhana, telur asin, bunga ajaib, paralayang, roket, akuarium mini, batik jumputan warna pelangi, ketapel, dan berbagai macam makanan dan minuman yang dihasilkan oleh anak pada saat pembelajaran sains.

Selanjutnya, dari hasil kuesioner dengan pertanyaan terbuka mengenai kendala dalam penerapan literasi sains dalam pembelajaran di PAUD, terdapat jawaban yang berbeda-beda dari setiap responden. Namun, jawaban terbanyak yang diungkapkan oleh guru-guru PAUD di Surakarta adalah; Pertama, guru belum pernah mengikuti pelatihan tentang pengembangan pembelajaran literasi sains di PAUD. Pelatihan mengenai pembelajaran literasi sains masih sangat jarang dijumpai oleh para guru PAUD. Padahal, berdasarkan penelitian yang dilakukan oleh Syaodih et al., (2021) menunjukkan bahwa kemampuan literasi sains guru PAUD secara keseluruhan mengalami peningkatan secara signifikan setelah mendapatkan metode pelatihan sains kreatif secara langsung. Sehingga, diperlukannya pelatihan-pelatihan mengenai literasi sains terhadap guru-guru PAUD.

Kedua, guru belum memahami bagaimana penerapan literasi sains, baik pada tahap perencanaan, pelaksanaan, sampai pada evaluasinya. Pada tahap perencanaan pembelajaran ini meliputi beberapa hal yaitu perumusan tujuan, media, materi sains, dan metode pembelajaran. Selanjutnya, untuk tahap pelaksanaan pembelajaran meliputi; guru membelajarkan kepada anak mengenai sebuah fenomena fenomena alam kemudian didiskusikan bersama, mendorong anak untuk ke perpustakaan sekolah atau lingkungan yang ada sekitar, serta mengintegrasikan literasi sains pada aspek yang lainnya, misalnya dengan seni, teknik, matematika, dan lain sebagainya. Terakhir yaitu tahap evaluasi pembelajaran. Pada tahap ini, guru dapat menilai sejauh mana pemahaman anak terhadap konsep, proses, dan konten penerapan sains (Noor, 2020).

Terakhir, sarana dan prasarana sekolah yang belum memadai. Hal ini sesuai dengan penjelasan (Avikasari et al., 2018) yang menyebutkan bahwa salah satu faktor yang mempengaruhi tingkat literasi anak ialah sumber belajar yang digunakan dalam kegiatan pembelajaran di kelas. Marwiyati \& Hidayatulloh (2018) mengungkapkan hal serupa bahwa dengan adanya fasilitas sekolah yang lengkap serta bervariasi akan membantu mengoptimalkan pembelajaran literasi anak dengan lebih cepat. Dengan sarana yang memadai dan guru yang kompeten, pendidikan tersebut akan berjalan baik dan lancar 
(Angrainy et al., 2020). Sarana prasarana yang dibutuhkan diinventarisir dengan baik agar dalam penyiapan proses pembelajaran berikutnya dapat disiapkan dengan baik.

Salah satu fasilitas atau prasarana pembelajaran yang dapat digunakan dalam mengembangkan literasi sains anak usia dini adalah melalui alat permainan edukatif. Hal ini sesuai dengan pendapat Widayati et al (2020) yang mengungkapkan bahwa literasi sains anak usia dini dapat dikembangkan dengan memanfaatkan alat permainan edukatif dalam bentuk konsep sains, proses sains, dan aplikatif sains.

\section{SIMPULAN}

Pada hasil analisis terhadap 64 guru PAUD menunjukkan bahwa sebagian besar guru telah mengembangkan literasi sains basis kelas. Namun, dalam praktiknya guru masih mengalami kendala. Permasalahan utama yang dihadapi guru untuk melaksanakan literasi sains adalah sekolah tidak memiliki tim literasi sains dan guru belum pernah mengikuti pelatihan pengembangan literasi sains di PAUD. Sehingga dibutuhkan evaluasi dan tindak lanjut lebih mendalam mengenai Gerakan Literasi Nasional, khususnya pada literasi sains di PAUD agar pengembangan literasi pada anak usia dini dapat diterapkan secara optimal.

\section{UCAPAN TERIMA KASIH}

Kami ingin mengucapkan terima kasih kepada Lembaga Penelitian dan Pengabdian Kepada Masyarakat (LPPM) Universitas Sebelas Maret yang telah memberikan dana penuh melalui skema Hibah Riset Grup Inovasi Pembelajaran PAUD tahun 2020 dan juga Program Studi Pendidikan Guru Pendidikan Anak Usia Dini untuk mendukung penelitian ini.

\section{DAFTAR PUSTAKA}

Aditomo, A., \& Faridz, N. F. (2019). Ketimpangan Mutu dan Akses Pendidikan di Indonesia: Potret Berdasarkan Survei PISA 2015. August. https:/ / doi.org/10.31227/osf.io/k76g3 Angrainy, A., Fitria, H., \& Fitiani, Y. (2020). Pengaruh Sarana Prasarana dan Lingkungan Kerja terhadap Kinerja Guru. Journal of Education Research, 1(2), 154-159. https:// doi.org/10.37985/joe.v1i2.15

Avikasari, A., Rukayah, R., \& Indriayu, M. (2018). The Influence of Science Literacy-Based Teaching Material Towards Science Achievement. International Journal of Evaluation $\begin{array}{lllll}\text { and Research in } & 182 .\end{array}$ https:// doi.org/10.11591/ijere.v7i3.14033

Barenthien, J., Lindner, M. A., Ziegler, T., \& Steffensky, M. (2020). Exploring preschool teachers' science-specific knowledge. Early Years, 40(3), 335-350. https://doi.org/10.1080/09575146.2018.1443321

Bosse, S., \& Anderson, T. L. (1946). Science on the Air. The American Biology Teacher, 8(4), 8687. https://doi.org/10.2307/4437688

Bybee, R. W. (2008). Scientific literacy, environmental issues, and PISA 2006: The 2008 paul FBrandwein lecture. Journal of Science Education and Technology, 17(6), 566-585. https:// doi.org/10.1007/s10956-008-9124-4

Citation, S. (2010). Exploring the Intersection of Science Education and 21st Century Skills. In Exploring the Intersection of Science Education and 21st Century Skills. https://doi.org/10.17226/12771

Garner-O'Neale, L., Maughan, J., \& Ogunkola, B. (2013). Scientific Literacy of Undergraduate Chemistry Students in the University of the West Indies, Barbados: Individual and Joint Contributions of Age, Sex and Level of Study. Academic Journal of Interdisciplinary Studies, 2(10), 55-66. https://doi.org/10.5901/ajis.2013.v2n10p55

Gerde, H. K., Pierce, S. J., Lee, K., \& Van Egeren, L. A. (2018). Early Childhood Educators' SelfEfficacy in Science, Math, and Literacy Instruction and Science Practice in the Classroom. Early Education and Development, 29(1), 70-90. https:// doi.org/10.1080/10409289.2017.1360127 
Husna Handayani, P., Handayani, P. H., Srinahyanti, \& Marbun, S. (2019). Science for Early Childhood Education: Practicality of Science Teaching Materials Oriented Science Literation for Early Childhood. 208(ICSSIS 2018), 4-6. https:// doi.org/10.2991/icssis$\underline{18.2019 .60}$

Jackman, H. (2012). Early education curriculum: a child's connection to the world. Integra Softwere Service Pvd, Ltd.

Kementerian Pendidikan dan Kebudayaan. (2017). Materi Pendukung Literasi Sains. Gerakan Literasi Nasional, 1-36.

Marwiyati, S., \& Hidayatulloh, M. A. (2018). Peran "Cakruk Baca Bergerak" Dalam Pengembangan Literasi Anak Usia Dini. AWLADY : Jurnal Pendidikan Anak, 4(2), 61. https://doi.org/10.24235/awlady.v4i2.3236

Mayer, R. E. (2004). Should There Be a Three-Strikes Rule against Pure Discovery Learning? The Case for Guided Methods of Instruction. In American Psychologist (Vol. 59, Issue 1, pp. 14-19). https://doi.org/10.1037/0003-066X.59.1.14

Morrison, G. S. (2012). Dasar-Dasar Pendidikan Anak Usia Dini (PAUD). PT. Indeks.

Noor, F. M. (2020). Memperkenalkan Literasi Sains Kepada Peserta Didik: Perspektif Calon Guru PIAUD. ThufuLA: Jurnal Inovasi Pendidikan Guru Raudhatul Athfal, 8(1), 056. https://doi.org/10.21043/thufula.v8i1.7066

NSTA Position Statement : Early Childhood Science Education Introduction. (2012). Nrc, 1-5.

OECD. (2019). PISA 2018 Assessment and Analytical Framework: Science, Reading, Mathematic and Financial Literacy. https://doi.org/10.1787/19963777

Omaga, J. F., \& Alieto, E. O. (2019). Teaching Literacy through Play: Perspective from Filipino Early Childhood Teachers. Online Submission, 31(3), 477-481.

Pereira, S., Rodrigues, M. J., \& Vieira, R. M. (2020). Scientific literacy in the early years-practical work as a teaching and learning strategy. Early Child Development and Care, 190(1), 64-78. https:// doi.org/10.1080/03004430.2019.1653553

Samsiah. (2018). Early Childhood Education Journal of Indonesia. Ijeces, 1(2), 1-8.

Şentürk, C., \& Sari, H. (2018). Investigation of the contribution of differentiated instruction into science literacy. Qualitative Research in Education, 7(2), 197-237. https://doi.org/10.17583/qre.2018.3383

Sliogeris, M., \& Almeida, S. C. (2019). Young Children's Development of Scientific Knowledge Through the Combination of Teacher-Guided Play and Child-Guided Play. Research in Science Education, 49(6), 1569-1593. https:// doi.org/10.1007/s11165-017-9667-6

Syaodih, E., Kurniawati, L., Handayani, H., \& Setiawan, D. (2021). Pelatihan Sains Kreatif pada Guru Pendidikan Anak Usia Dini. Jurnal Obsesi : Jurnal Pendidikan Anak Usia Dini, 5(2), 1854-1859. https:/ / doi.org/10.31004/obsesi.v5i2.771

Widayati, J. R., Safrina, R., \& Supriyati, Y. (2020). Analisis Pengembangan Literasi Sains Anak Usia Dini melalui Alat Permainan Edukatif. Jurnal Obsesi : Jurnal Pendidikan Anak Usia Dini, 5(1), 654. https://doi.org/10.31004/obsesi.v5i1.692

Zahro, I. F., Rissa, A. A., \& Munggaraning, S. W. (2019). Strategi pembelajaran literasi sains untuk anak usia dini. Jurnal Ilmiah Potensia, 4(2), 121-130. https://doi.org/10.33369/jip.4.2.121-130

ZR, Z., \& Eliza, D. (2020). Pengembangan Science Book Anak untuk Pengenalan Literasi dan Karakter Berbasis Budaya Alam Minangkabau. Jurnal Obsesi : Jurnal Pendidikan Anak Usia Dini, 5(2), 1567-1577. https:// doi.org/10.31004/obsesi.v5i2.896 